joule range, an inductor is more economical than a capacitor.

In the next session, investigations of temperatures of a thermal plasma in the range up to $20,000^{\circ} \mathrm{K}$., using the Holtsmark theory of spectral line broadening, as well as a microwave thermometer for millions of degrees based on the theory of abnormal microwave transmission of high-temperature gases in magnetic fields, were described by J. E. Drummond (Stanford Research Institute). Radiation effects on RankineHugoniot shock conditions were discussed by Hari K. Sen and Arnold W. Guess (U.S. Air Force), and a calculation of the radial distribution of photon emitters was described by Willard J. Pearce (General Electric).

The third session opened with a paper by E. I. Gordon (Bell Laboratories) on "Plasma Diamagnetism as a Diagnostic Technique". This was followed by a mathematical analysis of thermal diffusion at high temperatures in ionized gases by S. Chapman and E. Tandberg-Hanssen (High Altitude Laboratory, Boulder). Types of plasma motors were discussed by W. H. Bostick, and the design of a megatron, a plasma accelerator of the pulsed air-core betatron type (megagauss betatron), was outlined by $D$. Finkelstein (Stevens Institute of Technology). Experiments in plasma acceleration accomplished by the exploding wire ejection technique at low pressure were described by T. Korneff and J. L. Bohn (Temple Universiby); the wire between two parallel copper guides becomes the source of ions when a capacitor bank is discharged through it.
In the last session, on applications of plasma physics, a survey of problems of fusion propulsion was given by M. Clauser (Ramo-Wooldridge Corporation), and the feasibility of a thermonuclear propulsion system for, say, a future inter-planetary rocket with a 2,000 lb. pay-load was explored. A paper describing a high-temperature plasma generator, as well as some researches using this, was given by M. L. Ghai (General Electric). The plasma was obtained by high-temperature are discharges using as much as $4,000 \mathrm{~kW}$. of direct current power. A propulsion system using magnetic compression of the working fluid was analysed by A. E. Kunen and W. McIlroy (Republic Aviation), and a paper, mainly mathematical, on stochastic derivation of generalized macroscopic equations of change for reacting plasmas at extreme temperatures was read by H. J. Kaeppeler (Stuttgart). The behaviour of materials subjected to ultra-high temperature environments was described by J. H. Bonin and C. F. Price (University of Chicago); during the re-entry phase, hypersonic vehicles are exposed to high heat-flux rates, and to simulate these rates high-power arcs were used. An interesting cinefilm was shown of the behaviour of materials such as aluminium, stainless steel, copper, nickel, nylon and graphite under these conditions. Finally, M. A. Levine (U.S. Air Force) described interesting developments in the design of force-free coils in producing strong magnetic fields to meet the problems of thermal effects and of the Maxwell stress tensor effects of the coil.

\title{
CHILDREN AND SOCIETY
}

$\mathrm{T}$ HE British National Conference on Social Work is a voluntary organization which, since its inception in 1948, has taken the view that social work is an integral part of the effort made by the community to secure a better life for all. Membership of the Conference is open to any national social work agency in the United Kingdom, whether statutory or voluntary, which is in sympathy with its principles and aims. There are at present eighty voluntary and statutory bodies associated with the Conference.

It has two primary purposes : first, to conveneusually at intervals of three years-a national meeting to study specific social questions; secondly, to act in the United Kingdom as the national committee of the International Conference of Social Work, and in this capacity it is responsible for mobilizing interest in, and support for, international social service.

The third in the series of national meetings was held at Edinburgh during August 11-14, 1957, on the general theme of "Children and Young People". Many months in advance of the Conference, 158 study groups throughout the United Kingdom had considered a number of questions which had been put to them, and reviewed the post-war educational and social provisions made for children and young people. The views and findings of these study groups were made available to all members of the Edinburgh Conference*.

The Conference was attended by some 600 delegates and observers, including 40 visitors from overseas.

" "Children and Young People". (National Council of Socia Service, 26 Bedford Square, London, W.C.1.) 58. 6d.
Among those present were representatives of government departments, local authorities, teachers of social work at universities and schools, industrial personnel officers, officers of national voluntary organizations, and social workers from cities, towns, rural areas and new communities.

The relationship of children to their homes was examined by Prof. R. Ellis, of the University of Edinburgh, who mentioned three points of special interest. First, the long period of maturation of the human child, the learning of skills in the protective media of the family, and character formation as a positive imitation of what the child saw in the family circle. He also suggested the ingredients of the ideal home. Among those were regular employment for the father, the mother not forced to go out to work for economic reasons, and no focus of infection or discord. Mrs. Jean Mann, M.P., reminded the Conference of the number of deprived children in the care of local authorities, while Prof. Alan Moncrieff, of the University of London, and chairman of the Conference, discussed children who were maintained without payment by relatives and others. Nobody knew how many there were ; the statutory authorities were reluctant to promote legislation; he believed some of those children were treated as little household slaves. When the time came to have a new Children and Young Persons Act, it should be possible to introduce some sort of registration and supervision of these children. A large body of miserable children belonged to that group, and this may be because family life is more fluid than it had been in the past, due to the emancipation of women. On housing estates or in blocks of flats there 
be some provision for leisure-time activities where children could play and make a noise. In some new blocks of flats there should be a room available which children could use as a play centre. As a nation we were not doing an effective job with and for teenagers. Parents did not seem able to manage their teenage boys and girls, particularly girls. Mothers were not able to get on with their teenage daughters-could not moke friends with them; that was why there were so many 'beyond control' and 'care and protection' cases coming into the courts.

Mr. T. H. Hawkins, of Birfield, Ltd., suggested that while industry had a great deal to answer for in the way it had adversely influenced character formation in many young people, there had been great changes since the War, and to-day there were many employers who are not only concerned with their primary purpose of running successful businesses and making profits, but also recognize that their organizations have a social function to perform.

This point was supported by Miss F. Hornbrook, of the Ministry of Labour and National Service, who said that the firms where young people liked to work were those with good management, good working conditions, good training schemes and a good reputation in the neighbourhood.

In an address on young people and leisure, Sir Ben Bowen Thomas suggested that young people to-dey should be approached on the assumption that old social and economic divisions are on their way out, that community life is being articulated afresh, and that leisure activities are destined to hasten the process. Human relationships must conform increasingly to new social assumptions, social stratification counting for less and human association for more. "There is a threat only if we fail to humanize leisure. It holds an infinite promise of cultural creativeness and human happiness if.we succeed. If we are to be worthy of our dealings with young people who seem to be destined, in spite of great perils, to enter a world of fabulous possibilities, we must believe that leisure can be a means for cultured and civilized living for increasing numbers and that if our efforts are aimed at dealing with the spirits of young people in terms of their highest potential, we can help them to grow as human beings who will be equal to the moral requirements of their great estate".

\section{OUTPUT OF CHEMICAL ENGINEERS IN BRITAIN}

$\mathrm{R}$ EPLIES to a questionnaire sent by the Institution of Chemical Engineers to professors, heads of university departments, and principals of technical colleges in Great Britain regarding the present and future supply of chemical engineers and the difficulties experienced in obtaining suitable teaching staff, suggest that the country could provide 730 and 940 chemical engineers a year by 1959 and 1966, respectively, as compered with 277 in 1956.

The report "Scientific and Engineering Man-power in Great Britain" (H.M. Stationery Office, 1956) gives the total number of chemical engineers employed in Great Britain in 1956 as 1,500 and the total estimated number required by 1959 as 2,200 -an increase of 47 per cent. The survey shows that the output from the universities alone should be sufficient to meet this requirement. At the time of publication of the report on man-power, the actual total number of graduate and corporate members of the Institution of Chemical Engineers in Great Britain was approximately 2,100 , as compared with the figure of 1,500 given in the report.

The prospects in chemical engineering therefore appear to be good, but leave no grounds for complacency, especially when it is realized that the U.S.S.R., in relation to its population, trains three times as many professional engineers as the United Kingdom ("Engineering Education in the Soviet Union". Institution of Electrical Engineers, 1956). The estimates for 1959 appear to be somewhat optimistic, in view of the many difficulties in obtaining teaching staff described in the individual reports. These difficulties are real and widespread, and in general, rather worse in the technical colleges than in the universities.

The report on "The Supply and Training of Teachers for Technical Colleges" (H.M. Stationery Office, 1957) states that "for some years industry must be prepared to lose more than it may appear to gain.
The help which is given in such large measure during the evenings by industrial scientist and technologist is invaluable. With the rapid growth of day courses, however, their help during the day time will become increasingly necessary".

University teachers of chemical engineering are not generally very hopeful about the expansion of part-time day teaching by members of the staffs of industrial concerns. What is needed in the universities and colleges of advanced technology is the secondment from industry to teaching duties of qualified men with experience of part-time teaching in the evening, for periods of not less than six months, without loss of seniority.

There is justification for more interest and aupport from industry, not only in the problem of the shortage of teachers, but also in the extension of student apprenticeship schemes, coupled with study for university degrees ('thick sendwich'-type schemes); diplomas in technology (sandwich courses); and Higher National Certificates (part-time day release schemes). Student-apprentice schemes involving attendance at university courses are expensive-there is considerable capital investment in each candidate without guarantee of a return. The slow development of Higher National Certificate courses which are comparatively cheap from the point of view of industry suggests, however, that much more encouragement could be given than is at present apparent without incurring great expense.

A vigorous research school is an essential feature of a fully developed chemical engineering teaching department. It is doubtful, however, whether it is justifiable to retain at college for chemical engineering research a proportion as high as one-third of those with first degrees as the estimates for 1959 and 1966 indicate. In 1953, approximately 22 per cent of the members of the Institution of Chemical Engineers were employed on research and development. 